\title{
The Practice of Sustainable Tourism in Ecotourism Sites among Ecotourism Providers
}

\author{
Norajlin Jaini (Corresponding author) \\ Department of Parks \& Amenity Management, Faculty of Architecture, Planning \& Surveying \\ Universiti Teknologi MARA, 40450 Shah Alam, Selangor Darul Ehsan, Malaysia \\ Tel: 60-3-5521-1601 E-mail: nor_ajlin@yahoo.com
}

Ahmad Nazrin Aris Anuar

Department of Parks \& Amenity Management, Faculty of Architecture, Planning \& Surveying

Universiti Teknologi MARA, 40450 Shah Alam, Selangor Darul Ehsan, Malaysia

Tel: 60-3-5521-1554 E-mail: aek_2751@yahoo.com

Mohd Salleh Daim

Department of Parks \& Amenity Management, Faculty of Architecture, Planning \& Surveying

Universiti Teknologi MARA, 40450 Shah Alam, Selangor Darul Ehsan, Malaysia

Tel: 60-3-5521-1673 E-mail: salleh_daim1@yahoo.com

$\begin{array}{lc}\text { Received: November 14, } 2011 & \text { Accepted: December 22, } 2011 \quad \text { Published: April 1, } 2012 \\ \text { doi:10.5539/ass.v8n4p175 } & \text { URL: http://dx.doi.org/10.5539/ass.v8n4p175 }\end{array}$

The research is financed by Fundamental Research Grant Scheme (FRGS) sponsored by Ministry of Higher Education, Malaysia and Universiti Teknologi MARA.

\begin{abstract}
Ecotourism and sustainable tourism have similar objectives to link conservation goals, economic and rural development. Ecotourism also offers educational and new experience to tourists, and it has to be developed and managed in an environmentally sensitive manner while protecting the environment. With the influx of eco-tourist into Malaysia, the numbers of tourism agencies interested to be ecotourism providers increased tremendously. Since there are no specific guidelines in practicing ecotourism, many tourism agencies normally proclaim themselves as eco-tour providers and served in the ecotourism industry without any restriction. This situation will definitely affect the environment due to lack of proper ecotourism practice. Therefore, the aim of this study is to investigate the standard of the current ecotourism practice among ecotourism providers in Malaysia. The main objective of this research is to determine whether ecotourism providers follow sustainable tourism practices. An ecotourism provider in Selangor and Kuala Lumpur has been selected as the respondent. This study attempts to help in identifying the best practices for ecotourism in Malaysia towards sustainable tourism.
\end{abstract}

Keywords: Ecotourism, Ecotourism practice, Sustainable tourism

\section{Introduction}

Tourism is one of the important industries in Malaysia. In line of this, ecotourism has become one of the tourism activities preferred by the tourist. Ecotourism can be defined as one of the concept which focuses on conservation, preservation and has social and economic benefits. With the evolving of ecotourism industry, it is believed that it has been causing the number of travel agencies involved in ecotourism to increase. Consequently, when the number of tourism agencies increases in the ecotourism industry, it will definitely have the harmful effects if they do not strictly adhere to the practice of proper ecotourism. The objective of ecotourism is to provide a sustainable tourism whereby tourists enjoy the visit without causing any negative impact on sites while 
the communities get the benefit from the industry. However, the sustainability can only be achieved if they are really applying the ecotourism practices. Ecotourism providers are one of the important stakeholders that can facilitate towards sustainability. However, without following appropriate ecotourism practices, they will definitely contribute to the damage of ecotourism resources. With the growing concerns about the negative impacts of the ecotourism industry, it is necessary to follow the guidelines for sustainable tourism. The significance of this research, is that it may contribute indirectly towards the conservation of ecotourism areas in Malaysia.

\section{The Needs of Ecotourism in Sustainable Tourism}

In the 21 st century, sustainable development has become an important issue in our community. Sustainability highlights on the resource conservation. The model of sustainable development consists of three elements: economics, social and environment (Wildes, 1998). In line of this, the Tourism of Canada came up with the definition of sustainable tourism as development that leads to management of all resources to benefit the economic, social and aesthetic needs, while retaining the cultural, ecological and biological integrity (Cruz, 2003). The definition of sustainability is seen to move in line with the objective of ecotourism. Sustainability is a first thing to concentrate in order to perform for the best practice in ecotourism. Organizations such as The International Ecotourism Society (TIES), World Conservation Union (IUCN) and International Ecotourism Standard had explained the definition of ecotourism, which can be concluded that ecotourism is a travel or visit to a natural area while being responsible for the conservation and the impact of environment and benefiting the cultural, economic, social, and political landscape of the local people. It is also not solely to pursue for enjoyment, but also to provide appreciation for the environment and education for a tourist (Drumm \& Moore, 2005; Kaur, 2006). On the other hand, it was found that the definition of ecotourism has been misinterpreted and currently ecotourism is seen mainly as adventure tourism in a natural environment, with little concern for conservation and sustainability (Mader, 2002; Lascurain, 2006). This is due to lack of specific measures to guide the ecotourism activities. Therefore, the importance of indicators as a tool of sustainable tourism is needed.

\subsection{The Practice towards Sustainable Tourism}

To implement sustainable tourism, there is a need of the indicators, which perform a guide for ecotourism practice. These indicators can lead to an effective monitoring system (United Nation, 2007). World Tourism Organization (WTO) has developed a universal tourism indicator that is applicable to be used as a basis of sustainable tourism (Dymond, 1997). The eleven core indicators proposed by the WTO can be seen in Table 1 . Based on the Table 1, it is clearly comprised with the three important elements of sustainable tourism as mentioned previously. The elements of social, economics and environment has shown obviously in the indicators. There are many indicators, which comply with the elements of sustainable tourism. However, the indicators by WTO are perceived as a basis that should be used as a beginning in sustainable tourism.

\section{Methodology}

\subsection{Stage 1: Screening survey}

One of the limitations encountered in this research is the unavailability of a specific list of ecotourism agencies in Malaysia. The only means of finding the ecotourism providers was by going through the list of all the tourism providers in the country, which offer a range of tourism specialties. The purpose of the screening survey is to select and shortlist the eligible respondents for this research. The screening was carried out through a telephone survey. As for the agencies, which have fulfilled the criteria as an ecotourism provider, they will be asked for their consent and agreement to be involved in the next stage of the survey. Based on Table 2, the screening survey has shown that there were 976 travel agencies. However, only 97 agencies are directly involved in ecotourism. From the 97 agencies that have the potential respondents, only 78 of these agencies were willing to participate in the next survey. As such, 78 agencies have been selected as respondents for this study.

\subsection{Stage 2: Data Collection}

The questionnaire survey is the main instrument of data collection for this research. It was carried out by approaching agencies providing ecotourism activities in Selangor and Kuala Lumpur. They were the short-listed candidates during the screening survey. Based on screening survey, 78 of tourism agencies in Selangor and Kuala Lumpur have been identified to represent the required number of respondents. As the locations of the selected respondents were scattered around the country, the best way to distribute the questionnaire forms was through the Internet. It has decided to use email to send questionnaire forms, as its distribution is much faster and easier. However, from the 78 respondents, only 56 respondents replied to the questionnaire survey. Table 3 indicates the number of respondents of whom the researcher expected to get feedback. In order to answer the objective, the 
mean score range was used to identify either ecotourism provider fulfill the sustainable tourism on their practice through the scale rating in Table 4.

\section{Discussion}

In literature review, the indicators of sustainable tourism by WTO were comprised in four categories namely social, ecological, economic and planning. These categories are in line with the three elements of ecotourism that had been discussed in the literature review. Based on the result of the survey, the mean of eleven indicators of sustainable tourism practices has been ranked as shown in Table 5. The indicator of 'Tourism Contribution to Local Economy' collected the highest mean (mean=4.30) while 'Stress' was the lowest mean (mean=2.94). Based on the Table 5, level 1 is a satisfactory level where the mean value obtained was more than 4.00. Among the eleven indicators, the ecotourism providers have successfully practiced only four of it. The four indicators had gathered the mean value more than 4.00 , which has confirmed that the respondents "likely" to practice in that indicators. It also found that the practices were more successful in economic category. It can illustrate that there are two indicators from the economic categories. The economic category had attained a good result because it can provide a benefit to the local people and most importantly it can generate revenue to the agencies involved. As such, it would be vital for them to practice the economic indicators since it helps to strengthen the agencies financially. It also can be presumed that the ecotourism providers may focus on gaining profit for their agencies compare to other factors in their ecotourism business. The other two indicators were from social and planning categories whereas no successful indicator comes from ecological category.

For the second level, there were four indicators which obtained the mean value, which is "not sure," but it is inclined to be "likely" if some improvement was made on these indicators. Although the value is at a slightly satisfactory level, it was not really strong or insufficient to confirm as successfully practiced. The mean was between the ranges of 3.50 to 3.99. This mean can describe that the practices can improve and required some careful management. At this stage, the ecological category dominated the ranking as it was found that three of four indicators in this stage came from the ecological category, and one indicator came from the social category. From the result, it was found that 'local satisfaction' was in second level while the 'consumer's satisfaction' was in first level. It shows that the ecotourism providers were more concerned about their customers rather than the local people. However, this was not surprising because the customer satisfaction is on the economic category where it has a benefit to the agencies compared with the social category. Thus, the practice to ensure all groups of people had satisfaction was imbalanced because the ecotourism providers were more focused on one group. On the other hand, the ecological category seems not supposed to be in this level because it is one of the important elements in ecotourism. There is a need of a study on why this category is lacking in their practice.

The third level is the range of mean between the ranges of 3.00 to 3.49. It is also in the mean of "not sure" but this level is more crucial rather than the second level. There are two indicators inclusive in third stage: ecological and planning categories. This mean shows that the ecotourism providers had to get over the negative value and concluded as "unlikely" in their practices. For this level, the practices of an indicator required some precautionary measure; otherwise, it tended to be on the unsatisfactory level. The indicators included in this range were 'Development Control' and 'Waste Management'. It is considered that both indicators were on the management and practice for the site itself. It required a place attachment to the site so that they would feel more responsible for the site as well. The lack of responsibilities to the site caused the less practice for the indicators. The ecotourism agencies feel that the responsibilities must be held by the owner of the site.

The fourth level is the range below the mean of 3.00. The mean illustrated in negative value or unsatisfactory level. The indicator was 'Stress' from ecological category with the mean obtained as much as 2.94. This indicator represented the carrying capacity, which was the important factor in ecotourism industry. In WTO's indicators, it was the first indicator in the list, which shows that the existence of this indicator is vital. Regrettably, the ecotourism providers had proven that they were not concerned on one of the most important factors of sustainable tourism.

\section{Conclusion}

Although ecotourism in Malaysia had been developed for a long time ago, major gaps still existed in our industry, especially on the practice towards sustainable tourism. With the growing concern of the conservation issues in recent years, efforts to develop the best practice that measures environmental and social impacts of travel have increased. Many efforts to enhance ecotourism value as well as to improve its planning, management and marketing techniques have been carried out by the government and other stakeholders. However, the efforts still seem to be insufficient. There are still disturbing issues, which do not reflect the sustainable ecotourism, practices. 
Ecotourism providers need to improve on their practice. This is due to the findings, has shown the respondents have done successfully on only four among the eleven indicators. Most of the other indicators still need some expansion and awareness because some of the result had showed that the indicators obtained the mean in unsatisfactory level. Apart from that, an environmental element was seemed to be as very crucial where it does not show a great result on their practice. Sustainable tourism can be presumed as a new concept and need to gain better recognition in the Malaysian ecotourism industry. To achieve the best practice on ecotourism, the integration of sustainable tourism indicators seems as vital. It would benefit and enhance the ecotourism industry to ensure better operation of the ecotourism resources. As consequences, the practice and sustainability are closely related and need to be integrated, with each having its own role in ascertaining the direction of Malaysia's ecotourism industry.

\section{References}

Cruz, R.G. (2003). Towards Sustainable Tourism Development in the Philippines and Other Asean Countries. [Online] Available: http://pascn.pids.gov.ph (November 5, 2009)

Drumm,A. \& Moore, A. (2005). An Introduction to Ecotourism Planning. [Online] Available: http://www.parksinperil.org (November 17, 2009)

Dymond, S. J. (1997). Indicators of Sustainable Tourism in New Zealand: A Local Government Perspective. [Online] Available: www.informaworld.com (November 17, 2009)

Kaur, C.R. (2006). National Ecotourism Plan:Assessing Implementation of the Guidelines for Marine Parks. [Online] Available: http://www.docstoc.com (November 17, 2009)

Lascurain, C. (2006). ECOCLUB, International Ecotourism Monthly. [Online] Available: http://www.ecoclub.com (November 17, 2009)

Mader, R. (2002). Latin American Ecotourism: What is it? [Online] Available: http://www.commerce.otago.ac.nz (November 17, 2008)

United Nation. Indicators of Sustainable Development: Guidelines and Methodologies. [Online] Available: http://www.un.org (November 17, 2009)

Wildes, F.T. (1998). Influence of ecotourism in conservation for sustainable development: A case of Costa Rica. [Online] Available: http://www.geog.ucsb.edu (November 8, 2009)

Table 1. Core Indicators of Sustainable Tourism

\begin{tabular}{|c|c|c|c|}
\hline No. & Core Indicator & Specific Measures & $\begin{array}{l}\text { Indicator } \\
\text { Groupings }\end{array}$ \\
\hline 1. & Site protection & $\begin{array}{l}\text { Category of site protection according to the } \\
\text { International Union for the Conservation of Nature } \\
\text { and Natural Resources (IUCN) index }\end{array}$ & Ecological \\
\hline 2. & Stress & Tourist numbers visiting site (per annum/peak month) & Ecological \\
\hline 3. & Use intensity & Intensity of use in peak period (persons/hectare) & Ecological \\
\hline 4. & Social impact & Ratio of tourists to locals (peak period and over time) & Social \\
\hline 5. & Development control & $\begin{array}{l}\text { Existence of environmental review procedure or } \\
\text { formal controls over development of site and use } \\
\text { densities }\end{array}$ & Planning \\
\hline 6. & Waste Management & $\begin{array}{l}\text { Percentage of sewage from site receiving treatment } \\
\text { (additional indicators may include structural limits of } \\
\text { other infrastructural capacity on site, such as water } \\
\text { supply) }\end{array}$ & Ecological \\
\hline 7. & Planning process & $\begin{array}{l}\text { Existence of organized regional plan for tourist } \\
\text { destination region (including tourism component) }\end{array}$ & Planning \\
\hline 8. & Critical ecosystem & Number of rare/endangered species & Ecological \\
\hline 9. & $\begin{array}{l}\text { Consumer } \\
\text { satisfaction }\end{array}$ & Level of satisfaction by visitors (questionnaire-based) & Economic \\
\hline 10. & Local satisfaction & Level of satisfaction by locals (questionnaire-based) & Social \\
\hline 11. & $\begin{array}{l}\text { Tourism contribution } \\
\text { to local economy }\end{array}$ & $\begin{array}{l}\text { Proportion of total economic activity generated by } \\
\text { tourism only }\end{array}$ & Economic \\
\hline
\end{tabular}


Table 2. The Numbers of Tourism Agencies in Selangor and Kuala Lumpur

\begin{tabular}{|l|c|c|c|}
\hline Area & $\begin{array}{c}\text { No. of Tourism } \\
\text { Agencies }\end{array}$ & $\begin{array}{c}\text { No. of Agencies } \\
\text { Involved In Ecotourism }\end{array}$ & $\begin{array}{c}\text { No. of Agencies Willing To } \\
\text { Participate }\end{array}$ \\
\hline Selangor & 324 & 43 & 37 \\
\hline Kuala Lumpur & 652 & 54 & 41 \\
\hline Total & 976 & 97 & 78 \\
\hline
\end{tabular}

Table 3. The Number of Respondents and Responses Received

\begin{tabular}{|l|c|c|}
\hline Area & No. of Respondent & No. of Reply \\
\hline Selangor & 37 & 24 \\
\hline Kuala Lumpur & 41 & 32 \\
\hline Total & 78 & 56 \\
\hline
\end{tabular}

Table 4. Mean Score Range Towards Ecotourism Provider Are Fulfill the Sustainable Tourism On Their Practice

\begin{tabular}{|c|c|}
\hline Mean Score Range & Level of Efficiency \\
\hline$<3.00$ & Unsatisfactory \\
\hline 3.00 to 3.49 & Satisfactory With Precaution \\
\hline 3.50 to 3.99 & Satisfactory With Some Improvement \\
\hline$>4.00$ & Satisfactory Level \\
\hline
\end{tabular}

Table 5. The Level of Sustainable Tourism Practices

\begin{tabular}{|c|c|c|c|}
\hline Level of Mean & Variable & Category & $\begin{array}{l}\text { Mean } \\
(\mathrm{n}: 56)\end{array}$ \\
\hline \multirow{4}{*}{$\begin{array}{l}\text { Level 1: mean }>4.00 \\
\text { (satisfactory level) }\end{array}$} & $\begin{array}{l}\text { Tourism Contribution To Local } \\
\text { Economy }\end{array}$ & Economic & 4.30 \\
\hline & Social Impact & Social & 4.26 \\
\hline & Consumer Satisfaction & Economic & 4.14 \\
\hline & Planning Process & Planning & 4.01 \\
\hline \multirow{4}{*}{$\begin{array}{l}\text { Level 2: mean } 3.50 \text { to } 3.99 \\
\text { (satisfactory with some } \\
\text { improvement) }\end{array}$} & Critical Ecosystem & Ecological & 3.78 \\
\hline & Site Protection & Ecological & 3.75 \\
\hline & Local Satisfaction & Social & 3.69 \\
\hline & Use Intensity & Ecological & 3.58 \\
\hline \multirow{2}{*}{$\begin{array}{c}\text { Level 3: mean } 3.00 \text { to } 3.49 \\
\text { (satisfactory with precaution) }\end{array}$} & Development Control & Planning & 3.47 \\
\hline & Waste Management & Ecological & 3.15 \\
\hline $\begin{array}{l}\text { Level 4: mean }<3.00 \\
\quad \text { (unsatisfactory) }\end{array}$ & Stress & Ecological & 2.94 \\
\hline
\end{tabular}

